\title{
Comunicação e desenvolvimento: uma contribuição ao debate
}

\author{
César Ricardo Siqueira Bolaño*
}

O debate sobre comunicação e desenvolvimento precisa ser urgentemente retomado. Tema central nas discussões acadêmicas à época das políticas desenvolvimentistas na América Latina, o enfoque hegemônico naquele período foi justamente criticado, tanto pelas Teorias da Dependência, quanto, no campo da Comunicação, posteriormente, pela Economia Política e pelos chamados Estudos Culturais. Mas a crescente hegemonia adquirida pelos enfoques culturalistas, a partir dos anos 80, traduziu-se em uma desconfiança amplamente disseminada em relação à política e, com o tempo, a crítica se transformou no seu contrário, sob o influxo do paradigma da pós-modernidade e do pensamento único.

Enquanto isso, no mundo real, o capitalismo passava por uma mudança de época, com a Terceira Revolução Industrial, levada a cabo a partir do desenvolvimento da micro-informática e seus desdobramentos, sobretudo as tecnologias da informação e da comunicação, responsáveis por uma extensa subsunção do trabalho intelectual e uma "intelectualização" geral de todos os processos de trabalho e de consumo. Um novo capitalismo vai surgindo assim, marcado, ao contrário do longo período expansivo do pós-guerra, por uma forte exclusão social, acentuada agora pela exclusão digital, fenômeno novo, que alija as grandes massas da população mundial dos frutos do progresso, não apenas pela concentração do capital econômico, mas essencialmente também pela exigência de capital simbólico que o novo paradigma produtivo envolve.

O processo todo é extremamente enganoso, pois está ligado, pela própria "intelectualização" geral de que se falou, à expansão de processos de trabalho que exigem do trabalhador o desenvolvimento de ferramentas cognitivas mais complexas, o que muitas vezes pode ser visto unilateralmente como enriquecimento do trabalho, quando na verdade o que temos é um deslocamento de ênfase da exploração das energias físicas para as mentais do trabalhador na produção da mais valia, redundando em novas formas de especialização flexível, adequadas a uma extensa "precarização" do trabalho e consolidação de um importante desemprego estrutural.

É nessas condições e não outras que a comunicação e a informação invadem o modo de produção e todos os setores da vida. Assim também os meios de comunicação de massa ganham relevo e passam por uma concentração ainda mais ampla do que aquela denunciada pelos estudos comunicacionais dos anos 60 e 70. Desta forma, é urgente retomar a questão da Comunicação e Desenvolvimento, em novas bases e perspectivas.

O Laboratório Interdisciplinar sobre Informação e Conhecimento (Liinc), parceria da Universidade Federal do Rio de Janeiro (UFRJ) e do Instituto Brasileiro de Informação em Ciência e Tecnologia (Ibict) tem se consolidado como um espaço institucional e multidisciplinar para a reflexão crítica sobre informação, conhecimento e desenvolvimento, no contexto das transformações do mundo contemporâneo e este número da revista, em particular, foi pensado para servir como estímulo à discussão dessas questões. Não se trata de um dossiê, com textos encomendados, seguindo uma determinada ordem de preocupações, mas de um apanhado de

\footnotetext{
* César Ricardo Siqueira Bolaño é Doutor em Economia e professor do Departamento de Economia da Universidade Federal de Sergipe.
} 
artigos encaminhados ao conselho editorial, a partir de uma chamada pública de trabalhos, os quais foram avaliados entre outros e aceitos para publicação, como é característica da revista.

Assim, o que temos é um material bem diversificado, mostrando diferentes faces dos debates travados hoje, nesse sentido, nos campos das Ciências da Informação e da Comunicação e de áreas afins. O número conta com um texto de opinião, de Luiz Carlos Santos Lopes, sobre "A comunicação e o desenvolvimento da sociedade", e quatro artigos: "Sociedade e tecnologia digital: entre incluir ou ser incluída", de Adilson Cabral; "Apreensão e construção do conhecimento científico: descompasso entre necessidades informacionais e pensamento crítico", de Aida Varela Varela e Igor Guimarães; "Mais e melhores relacionamentos: uma proposta de metodologia de gestão da comunicação em arranjos produtivos locais", de Rosa Lima; e "Políticas públicas para o livro e a leitura e sua influência na indústria editorial de Salvador", de Susane Barros, Jussara Borges e Othon Jambeiro. 